\title{
КОМПЛЕКСНЕ ДОСЛІДЖЕННЯ МИТРОПОЛИЧОГО САДУ КИСВО-ПЕЧЕРСЬКОЇ ЛАВРИ
}

\author{
THE METROPOLITAN GARDEN OF KIEV-PECHERSK LAVRA: \\ COMPREHENSIVE RESEARCH
}

\begin{abstract}
Modern urban development in Ukraine can hardly be called controlled. Irrational, uncomfortable and even aggressive housing development poses a threat to historic buildings and urban ecology. The territories of the national preserves are legally protected from any arbitrary actions of developers. The Metropolitan Garden of the "Kyiv-Pechersk Lavra" National Reserve may serve as a striking example of a comprehensive study and a basis for sustainable development of the urban environment. For decades, this location has been the subject of interdisciplinary research.

An archaeological study in this area began in the 1950s and, intermittently, has been continued. During that time, many archaeological monuments of different types and from different historical periods have been discovered. Some of them are researched more than others, but together they mirror the main stages of the Metropolitan Garden's historical development and reflect the changes in the way it has been used.

As a result of many years of research, more than 700 square meters have been surveyed; they can be divided into four main cultural and chronological layers: 1) the Early Iron Age $\left(6^{\text {th }}-5^{\text {th }}\right.$ centuries BC), 2 ) the period of Kievan Rus' $\left(9^{\text {th }}-13^{\text {th }}\right.$ centuries $), 3$ ) the Russo-Lithuanian period of the $14^{\text {th }}-16^{\text {th }}$ centuries, 4) modern times $\left(17^{\text {th }}-19^{\text {th }}\right.$ centuries). The archaeological research has resulted in data on the Metropolitan Garden's primary relief and identification of two periods of natural and anthropogenic development of the location. This was accompanied by an archaeological study, historical studies of the Archimandrit's Garden and its transformation into the Metropolitan Garden as well as the peculiarities of its planning structure.

The article also presents reconstructions of all the types of the flora that could have grown in the Pechersk Monastery since Kievan Rus' and a the study of the vegetation of the existing garden since the $17^{\text {th }}$ century.

Today the authorities are considering creation of an Archaeological Park within the Metropolitan Garden of the National Reserve "Kiev-Pechersk Lavra".
\end{abstract}

Keywords: Kiev-Pechersk Lavra, archaeology, vegetation, sustainable development.

* ORCID: 0000-0003-0590-9726, Національний заповідник „Києво-Печерська лавра”, Україна 01015, м. Київ, вул. Лаврська, 9, taransun@ukr.net. 
Анотація. Сучасний урбаністичний розвиток, надто в українських реаліях, навряд можна назвати контрольованим. Місцями хижацька, нераціональна та некомфортна забудова - дамоклів меч не тільки історичної забудови, а й екологічних проблем. Території заповідників є гарантовано захищені державою від будь-якого свавілля забудовників. Митрополичий сад Національного заповідника „Києво-Печерська лавра” як яскравий приклад комплексного вивчення та збереження - основа сталого розвитку міського середовища. Ця локація протягом десятків років є об'єктом багатовекторного дослідження.

Археологічне вивчення цієї території розпочалося в середині минулого століття i, 3 певними перервами, продовжується до сьогодні. За цей час тут виявлено і повністю або частково досліджено низку різних за типом та хронологією археологічних пам'яток, комплекс яких доволі точно віддзеркалює основні етапи історичного розвитку зазначеної території та епохальні зміни в характері їі використання. У результаті багаторічних досліджень тут розкрито понад $700 \mathrm{M}^{2}$ і встановлено наявність чотирьох основних культурно-хронологічних горизонтів, а саме: пам'яток ранньозалізного віку (VI-V ст. до н.е.), періоду Київської Русі (XI-XIII ст.), Русько-Литовського періоду (XIV-XVI ст.), доби Модерну та Нового часу. Завдяки археологічним дослідженням ми отримали дані про первинний рельєф території Митрополичого саду та змогли виділити два періоди природно-антропогенного розвитку цієї локації.

Паралельно 3 археологічним вивченням проходили історичні студії Архімандричого саду 3 його трансформацією в Митрополичий, визначалися особливості його планувальної структури. У статті представлені реконструкції всіх типів флори, які могли рости у Печерському монастирі, починаючи 3 періоду Київської Русі, та дослідження рослинності вже існуючого саду з XVII ст. до наших днів. Сьогодні розглядається ідея створення Археологічного парку на території Митрополичого саду Національного заповідника „Києво-Печерська лавра”.

Ключові слова: Києво-Печерська лавра, сад, археологія, рослинність, сталий розвиток.

На сучасному етапі археологічне дослідження будь-якої локації урбаністичного середовища важко уявити без комплексного вивчення території як історико-топографічного, так і геолого-ландшафтного. Але навіть при максимальному рівні вивчення ділянки необхідно, як один з результатів дослідження, готувати проект про сталий розвиток / sustainable development локації. Ситуація стає більш відповідальною, якщо мова йде ще й про збереження природних анклавів міста. Саме таким є об'єкт дослідження - Митрополичий сад Національного заповідника „Києво-Печерська лавра”.

Назва локації відповідає дійсності, на сьогодні це дійсно сад, загальна площа якого становить близько 0,9 га. У ньому налічують понад 100 плодових дерев і кущів (яблуні, груші, абрикоси, вишні, волоські горіхи, дерен, бузок та ін.). До доволі нечисленних збережених історичних насаджень належать 9 дерев кизилу (дерену)/, вік яких, за оцінками вчених-біологів, налічує понад 300 років, що мають статус пам'ятки природи та включені до природно-заповідного фонду України, а також до Списку 500 видатних дерев України (Романченко 2017, с. 235) (рис. 1). Історія антропогенного використання території Митрополичого саду нараховує не менше 2,5 тисяч років. Звичайно такі висновки отримані завдяки археологічним дослідженням, що, вочевидь, $\epsilon$ домінантними у комплексному вивченні локації до появи першого писемного згадування про сад у 1654 році (Халебський 2008, с. 138-139). Розглянемо всі аспекти розвитку та вивчення цієї території. 


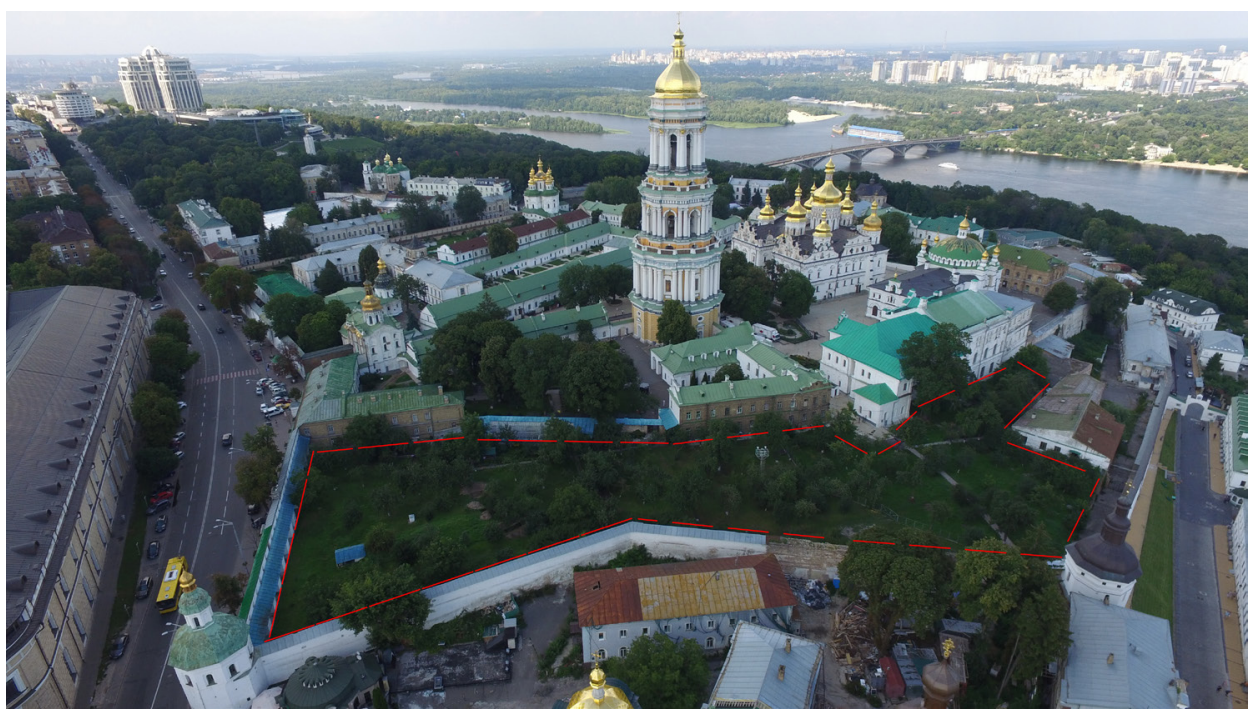

1. Сучасна територія Митрополичого саду Національного заповідника „Києво-Печерська лавра" (фото В. Гнери)

\section{ВИВЧЕННЯ ПЕРВИННОГО РЕЛЬЕФУ ТЕРИТОРІЇ МИТРОПОЛИЧОГО САДУ}

Спеціальні дослідження природного ландшафту території Києво-Печерської лаври не проводилися, хіба що можна зазначити спорадичні додаткові спеціальні дослідження лаврських печер, пов'язані зі збереженням їх від руйнації. Тому вивчення давнього рельєфу Митрополичого саду можна пов'язати виключно з археологічними дослідженнями. Під час розкопок 2017 р. київський ландшафтознавець кандидат географічних наук С.П. Романчук провів геоморфологічні дослідження, які надали додаткові матеріали про первинний ландшафт цієї території (Тараненко, Мисько, Балакін та Пабат 2017, с. 179-180) (рис. 2:17.1).

Ділянка Митрополичого саду розташована в крайовій частині Печерського плато - лесової ерозійно акумулятивної рівнини середньоантропогенового віку на неогеновій підвищеній основі. Крайова частина плато завдяки своєму розташуванню між макро-схилом до долини Дніпра та так званим Лаврським яром-балкою, має слабо похилу поверхню (1-5²), абсолютні відмітки якої становлять 180-188 м. Крайова присхилова частина досить різко переходить до спадистих (часто більше $30^{\circ}$ ) схилів до Дніпра і згаданого яру, що тисячі років сприяло розвитку прискорених процесів денудації (ерозійних та зсувних), тим паче, що лесова товща потужності 15-20 м дуже вразлива до впливу поверхневого стоку (при відсутності рослинності) (рис. 3). 


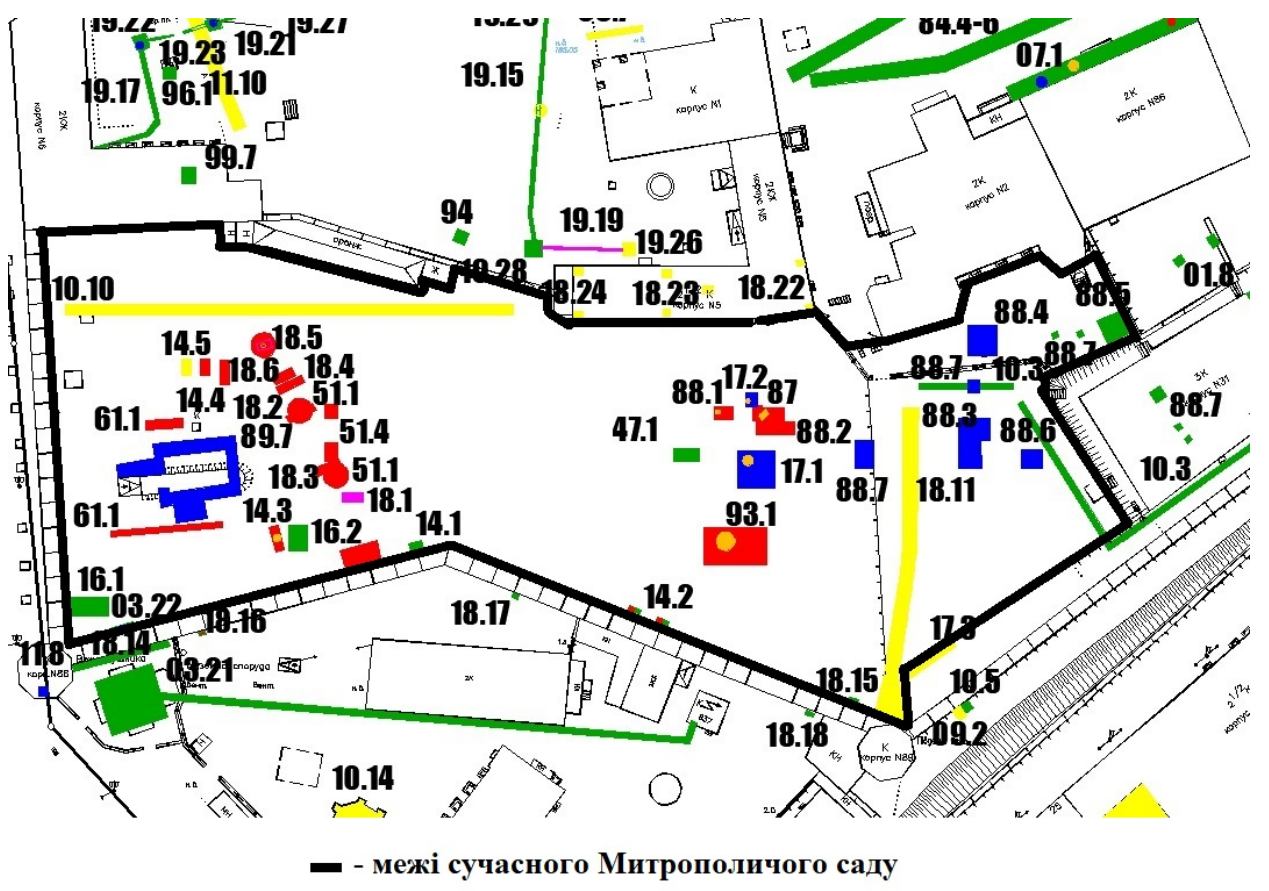

2. Фрагмент Археологічної карти території Національного заповідника „Києво-Печерська лавра"

Завдяки позиційно-динамічному розташуванню лесових порід їх переміщення вниз по схилу стало явищем постійним, хоч і диференційованим в часі за певними етапами природокористування, і грунт, як „пам’ять ландшафту”, повинен їх конкретизувати.

Стратиграфія стінок розкопів і шурфів свідчить про погану збереженість верхніх генетичних горизонтів грунтового профілю. Автентичним можна вважати (i то з певними застереженнями) горизонт на глибині більше 1 м від денної поверхні (археологічний передматерик. авт.). Брунатно-плямистий вигляд і важчий механічний склад (порівняно з грунтотворчою породою) свідчать про його приналежність до сірого лісового грунту (рис. 4:1). Цей тип грунту є переважаючим для лесових розчленованих рівнин лісостепу та лесових островів Полісся. Сірі лісові грунти формуються під широколистяними лісами (переважно дібровами різного складу). Грунт формується під дією промивного режиму в присутності кислот, які утворюються під час розкладу органічних решток лісової і трав'янистої рослинності.

Вище цього горизонту залягає міксований шар 3 матеріалами ранньої залізної доби (рис. 4:2). Така ситуація може свідчити, що в той час верхні генетичні горизонти сірого лісового грунту вже не існували. 3 великою 


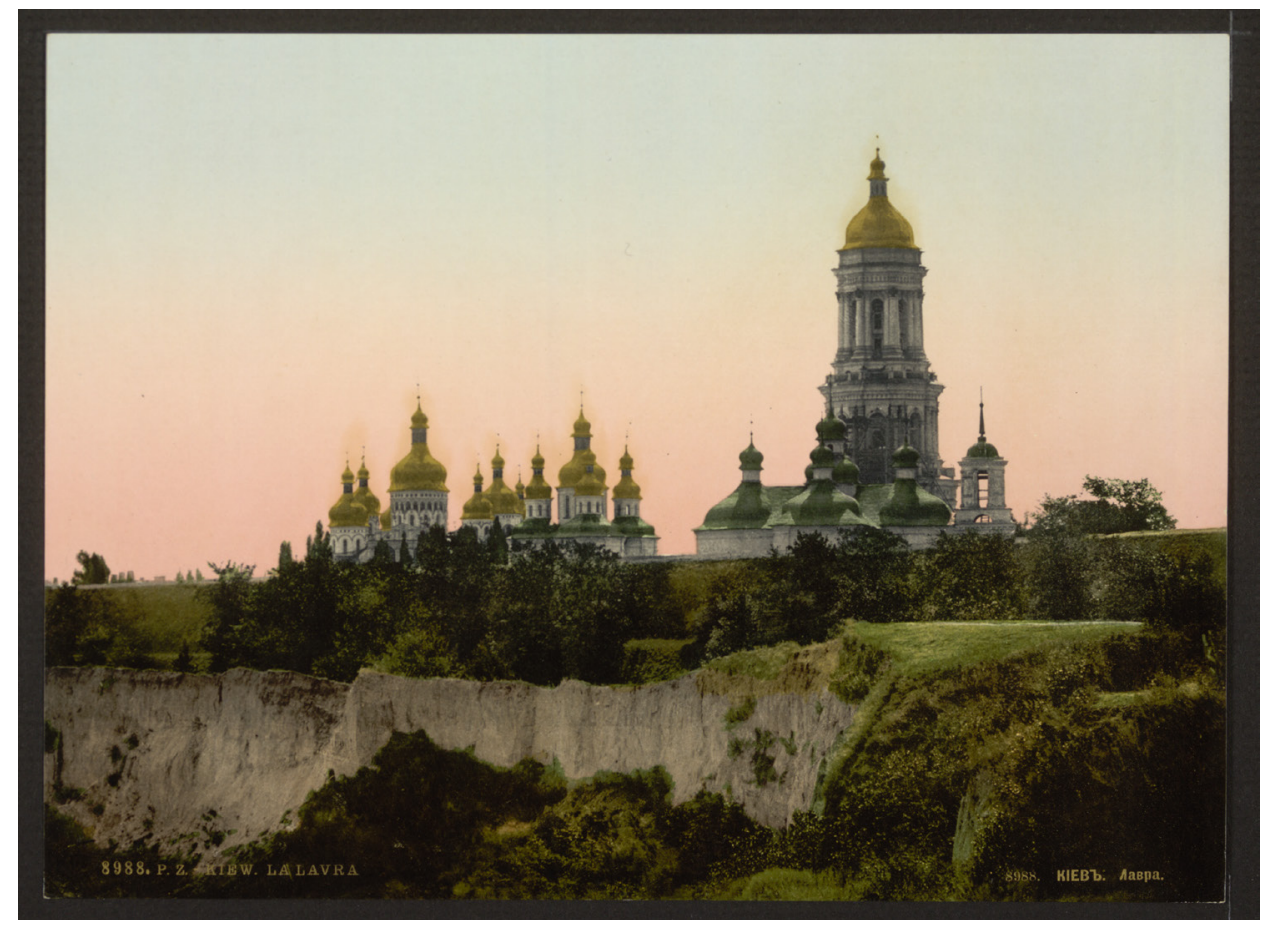

3. Києво-Печрська лавра на схилах Печерського плато (поштова листівка. Detroit, Mich., Detroit Publishing Company [1890-1900]. (Retrieved from the Library of Congress, https:// www.loc.gov/item/2001697429/)

вірогідністю можна припустити, що це урочище було перетворено на ріллю, як і більшість відносно рівних ділянок плато, а ерозійні процеси на краю схилу довершили справу руйнування грунту. Цей процес переміщення орного шару на схилі можна порівняти із сповзанням скатертини зі столу. Внаслідок цього накопичується матеріал біля підніжжя схилів, утворюються наорані тераси, тощо. Судячи з масштабів руйнування грунту, цей процес міг періодично тривати аж до ХІ ст. включно, а тому не виключено, що культурний шар ранньої залізної доби міг був зруйнований вище по схилу і переміщений оранкою на місце сучасного розкопу.

Пізніші нашарування з'явилися в результаті зміни господарських функцій території. Підвищена гумусованість може свідчити про припинення ерозійних процесів в результаті запровадження городництва і садівництва 3 внесенням органічних добрив і впорядкуванням території монастиря (рис. 4:3).

Однак зростання поверхні на 50-60 см не могло відбуватися лише за рахунок добрив. Головне надходження матеріалу відбувалось за рахунок навколишніх будівельних робіт. Траншеї під фундамент, фортифікаційні наземні споруди і підземні порожнини споруджувались кількасот років, а грунт 


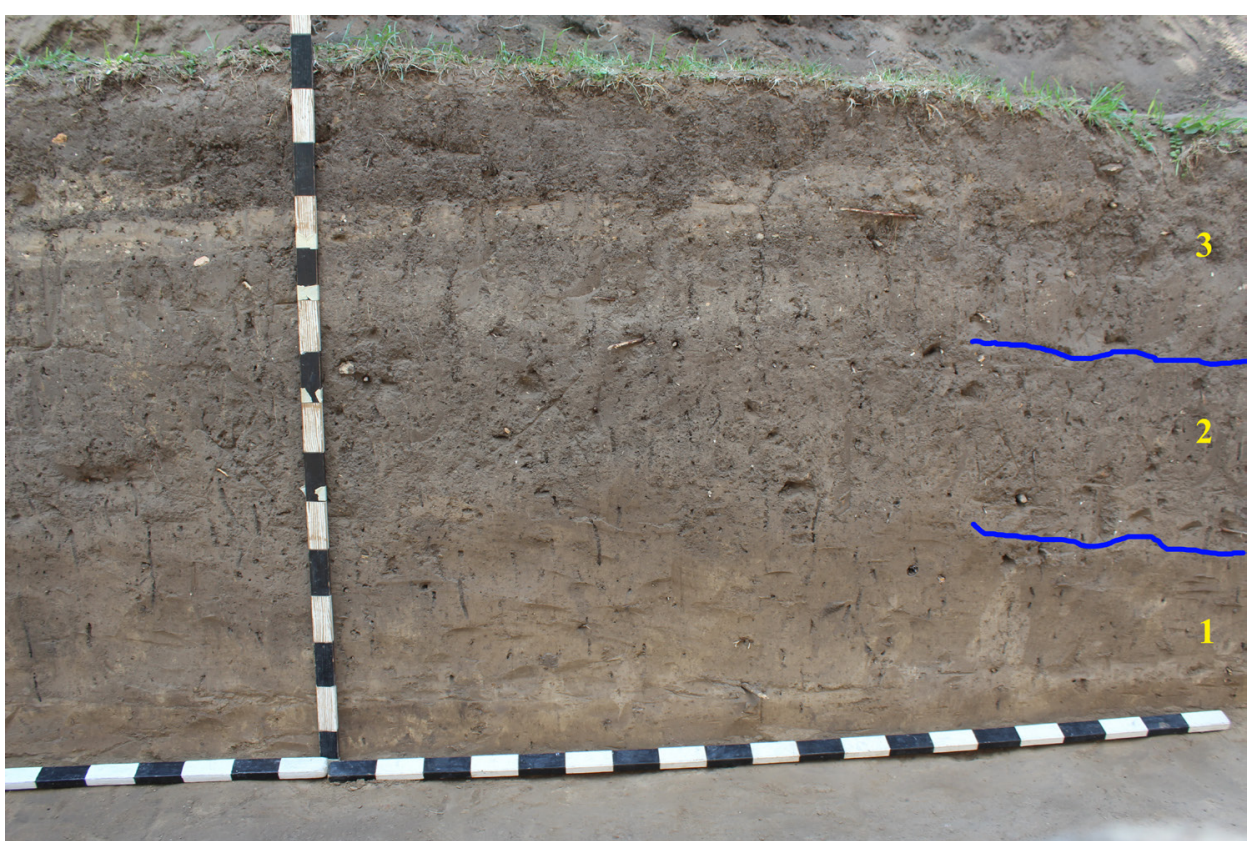

4. Стратиграфія південної стіни Розкопу 1 (розкопки С. Тараненко 2017 р.)

розсипали поблизу, який разом 3 культурними рештками створив культурний шар у вигляді культурного грунту, який уже не має нічого спільного 3 природним - автентичним (крім процесу гуміфікації).

Таким чином, спостерігається, як мінімум, два періоди природно-антропогенного розвитку території Митрополичого саду: руйнування природного сірого лісового грунту під дією збезлісення, оранки та ерозійних процесів та стабілізація прискорених ерозійних процесів під дією техногенних чинників і зміни господарської функції (від ріллі до саду-городу). На момент побудови наземних споруд монастиря (до XI ст.) поверхня плато найімовірніше була відкритою і використовувалась як переліг (чергування ріллі і пасовища).

\section{АРХЕОЛОГІЧНІ ДОСЛІДЖЕННЯ}

Найраніший культурний шар про який йшлося вище, це ранньозалізна доба, тому наступний блок досліджень пов'язаний з археологічними дослідженнями. Матеріали цього періоду у вигляді перевідкладених керамічних знахідок спорадично трапляються по всій верхній території Лаври (Тараненко 2019, с. 344-352). Зазвичай іх ідентифікували як приналежні до скіфських або підгірцівських старожитностей, але археологічний об'єкт був зафіксований 

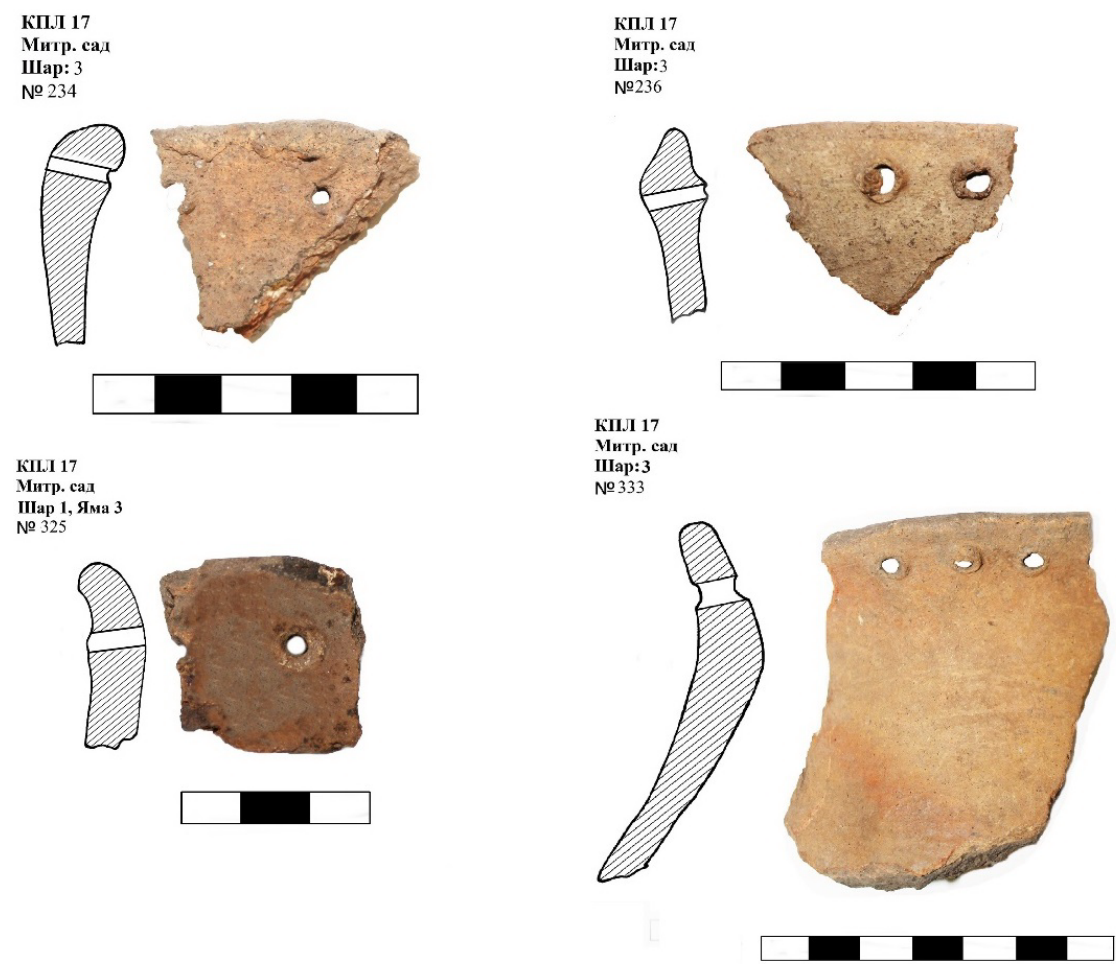

5. Кераміка скіфського часу києво-черкаської групи, друга половина VII-V ст. до н.е. (розкопки С. Тараненко 2017 р., рис. О. Махота)

лише на ділянці Митрополичого саду (рис. 2:87). Це грунтове поховання підгірцевської культури раньозалізного віку $\mathrm{V}$ ст. до н.е. на глибині 1,3 м від сучасної денної поверхні: кістяк скорчений, на правому боці, головою на схід. Інвентар: два невеликі горщики, миска, кістяне втульчасте вістря стріли. Поховання належало юнакові 15-16 років, на черепі сліди травми (Гончар 1993, с. 176). Досліджений об'єкт, вірогідно, є окремим грунтовим похованням, а не частиною могильника. Подібні поодинокі поховання відомі у межиріччі Ірпеня та Росі. Цей регіон характеризується контактами місцевих хліборобів 3 племенами лісової зони, які активно проникають у регіон вже в ранньоскіфський час (Гречко 2014, с. 85).

Окремі керамічні знахідки зафіксовані на території Митрополичого саду під час археологічних досліджень у 1988, 1993, 2014 та 2017 рр. (рис. 2:88.1; 93.1; 14.3; 17.1; 17.2). Під час останніх отримана колекція ліпної кераміки ранньозалізного віку налічує 24 фрагменти різного розміру. За характерними особливостями формувальної маси, орнаментації та форми вони можуть 

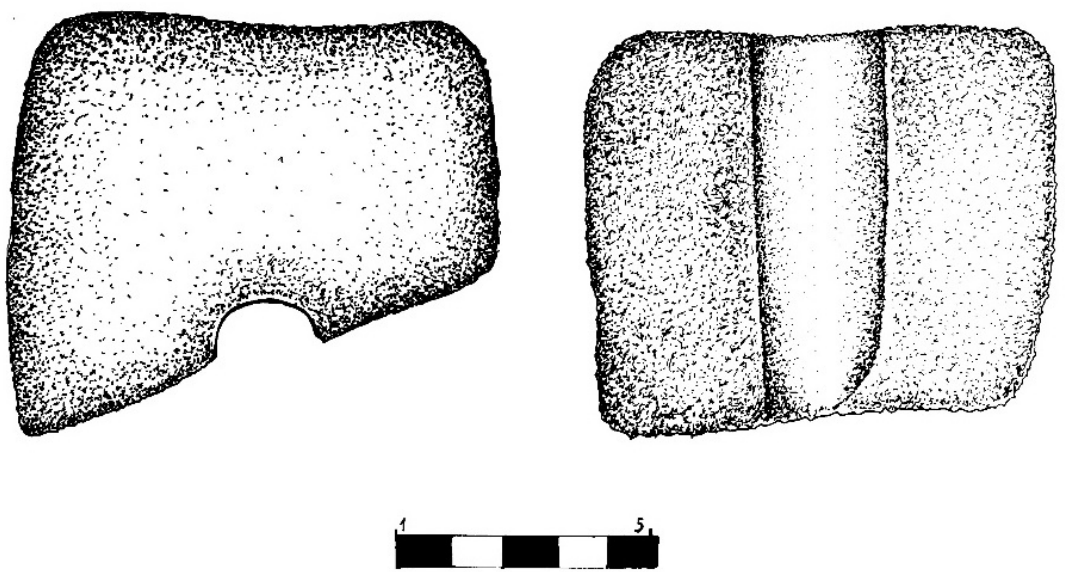

6. Кам’яний молот VII-V ст. до н.е. (розкопки С. Тараненко 2017 р., рис. О. Махота)

належати до кола пам'яток скіфського часу києво-черкаської групи, і бути датованими другою половиною VII-V ст. до н.е. (рис. 5). Старожитності Київщини (Хотівського локального варіанту) $є$ найбільш північною частиною зазначеної групи (Максимов та Петровська 2008). 3 шурфу 1 походить фрагмент кам'яного молоту, виготовленого з граніту. Він сірого кольору, розмірами $7,0 \times 8,0 \times 7,0$ см, має отвір округлої форми діаметром 2 см, призначений під держак (рис. 6). Враховуючи його підпрямокутну форму і відсутність слідів використання, можна припустити, що виріб не був остаточно завершений і залишився на стадії заготовки (Тараненко, Мисько, Балакін та Пабат 2017, c. 179-180).

Наявної сьогодні інформації для чіткої типологічної атрибуції культурного шару ранньозалізного часу поки що недостатньо. $С$ кілька версій, за однією 3 них територія Заповідника розглядалася як транзитна ділянка на шляху регулярного сезонного перегону стад з літніх пасовищ на зимові (Балакін 2017, с. 125), за іншою - могло трапитися «сповзання» матеріалу протягом кількох століть з об'єктів раннього залізного віку, які розміщаються на вищих відмітках Печерського плато. Не виключено, що таке поселення ще знайдено і розташоване десь поруч, у будь-якому випадку відповідь можуть дати тільки наступні стаціонарні дослідження.

Наступний період використання цієї території - Київська Русь (XI - перша пол. ХІІІ ст.). У давньоруський час ця територія потрапляє в зону господарської діяльності Печерського монастиря і використовується як виробнича зона часів спорудження (1073-1077 рр.) та оздоблення (1083-1089 рр.) Успенського собору. Підтвердженням цього $є$ фіксація склоробної майстерні (рис. 2:51.4). У 1951 р. В. Богусевич у Митрополичому саду Києво-Печерської 


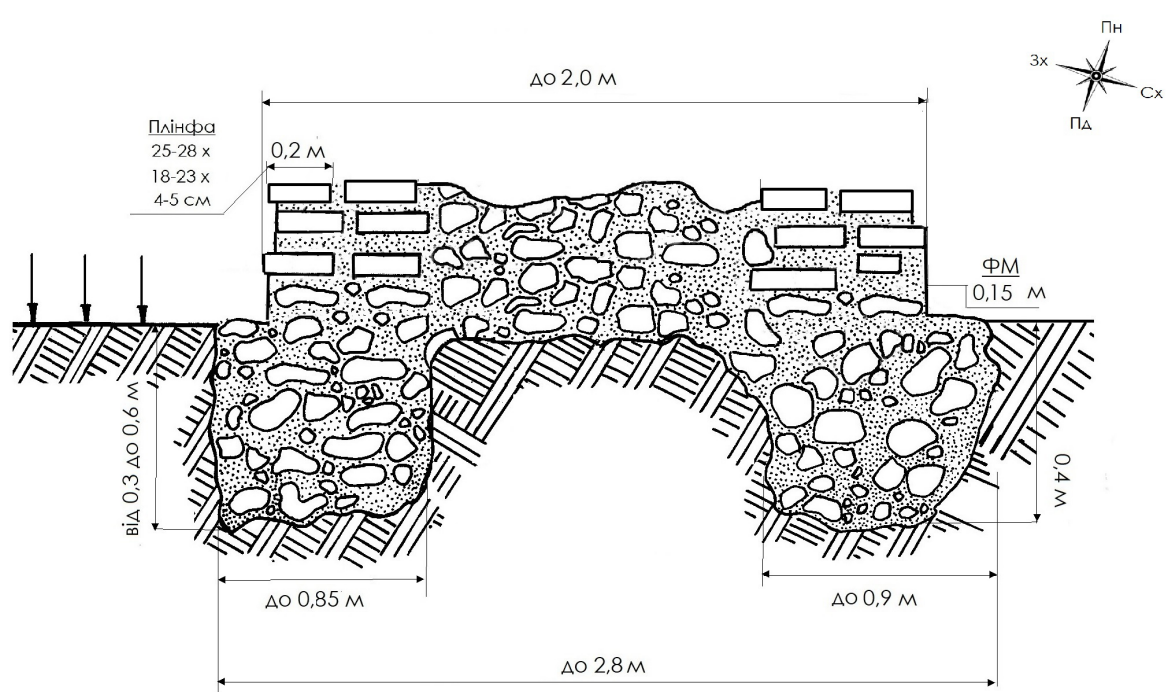

7. Реконструкція мурів XII ст. Печерського монастиря (автор С. Тараненко)

лаври дослідив рештки двох споруд, пов'язаних із склоробно-смальтовим виробництвом (горни), що складалися з плінфи XI ст., глини та шиферних плит. Серед матеріалу виділяються плінфа, вкрита шарами різнокольорового переплавленого скла; зливки скла різного розміру; заготовки різнокольорової смальти; фрагменти стінок різнокольорового скляного посуду типу стопок; віконного скла; уламки керамічних тиглів двох видів із скляною масою; фрагменти поливаних плиток; скляні краплі; шматки свинцю, заліза, кобальту та сірки (Богусевич 1954). Наукова цінність унікального комплексу підкреслена висновками хіміко-технологічних аналізів, проведених М. Безбородовим (Безбородов 1956). У склоробній майстерні на території Митрополичого саду працювали як візантійські, так місцеві майстри. Важливими $є$ висновки В. Богусевича що цей виробничий центр орієнтувався виключно на монументальне будівництво і майстерні припинили своє існування вже у XII-XIII ст. (Богусевич 1954). Це підкреслює, що їх робота була пов'язана передусім із оздобленням Успенського собору в 1083-1089 pр.

Вірогідно, під час функціонування склоробного комплексу у другій половині XII ст. 3'явилася мурована монастирська огорожа і ця територія стала однією зі складових частин території Печерського монастиря. Перше археологічне відкриття монастирських мурів сталося у 1951 р. на території Митрополичого саду Києво-Печерської лаври (Асєєв та Богусевич 1951) (рис. 2:51.1; рис. 8). За розмірами плінфи та способом будівництва вона була визначена 


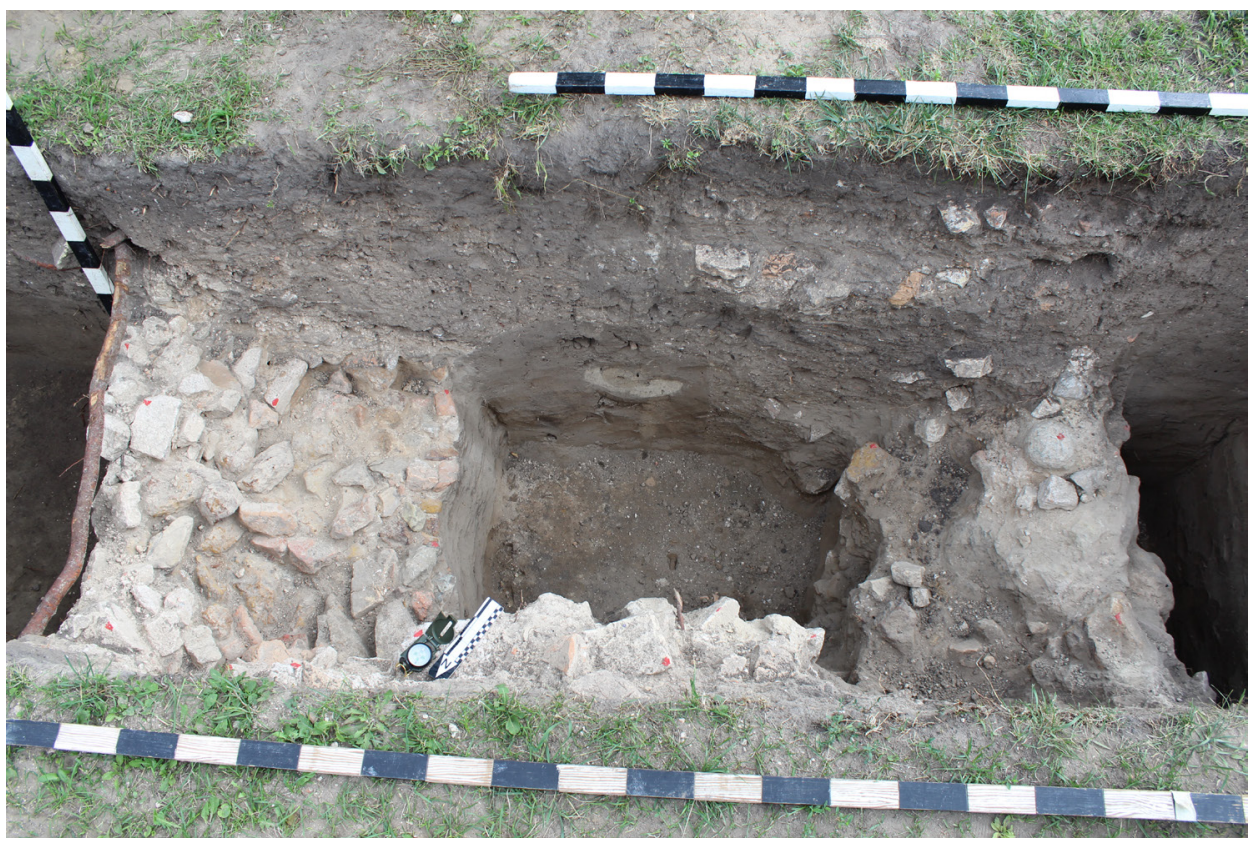

8. Траншея 4. Мури XII ст. Печерського монастиря (розкопки С. Тараненко 2018 р.)

В. Богусевичем як фортечна стіна. У 2018 р. проводилися археологічні дослідження з метою верифікації даних 1951 р. та пошуку нових ділянок. У двох 3 шести траншей (траншеї 2, 5) на місці розкопів В. Богусевича повторно та у трьох траншеях поруч (траншеї $3,4,6)$ вперше виявлено залишки монументальної конструкції давньоруського часу - фундаменти різного ступеню збереженості та напівзруйновані фрагменти стіни і фундаментного майданчика (рис. 2:18.1-5; 9) (Тараненко 2018; Тараненко та Кабанець 2019). Дослідження 1951 та 2018 рр. дозволили підготувати реконструкцію мурів Печерського монастиря XII ст. (рис. 7).

Фундамент складався 3 двох паралельно розміщених ровів, забутованих, крім нечисленних фрагментів плінфи, камінням, яке складалося з осадових (польово-шпат-кварцеві та залізистий пісковики; вапняк брекчійований, окремнілий; кварцито-пісковики), метаморфічних (гнейс, амфіболіт, кварцит) та магматичних (граніти) порід. Камені в більшості мають гострокутну форму, що свідчить про їх механічну обробку (рис. 8). Глибина закладки ровів коливається від 0,3 до 0,6 м, ширина - близько 0,9 м. Таким чином, загальна ширина фундаментів фортифікаційної стіни монастиря була до 2,8 м.

Верхня частина фундаментів являє собою вирівняний майданчик, складений з фрагментів плінфи, залитих білим вапняним розчином та, у менший мірі, рожевим вапняно-цем'янковим розчином. Його потужність - до 0,15 м. 


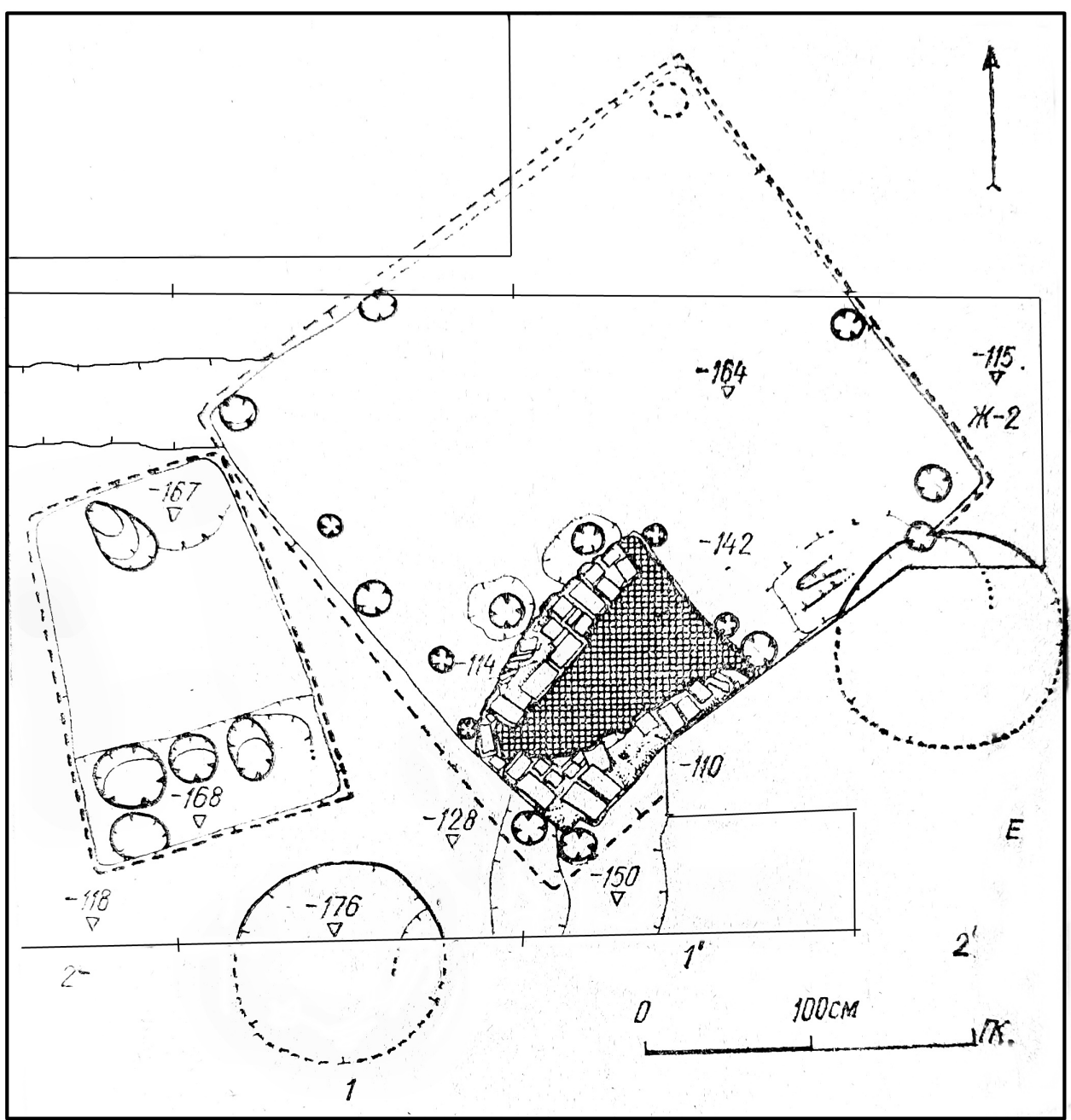

9. Споруда №2 (розкопки В. Харламова, 1987 р.)

Фундаментний майданчик був основою для зведення наземної частини муру, яка у 2018 р. була зафіксована тільки в одному випадку у вигляді ряду 3 двох плінф (траншея 4). Це підтверджує думку В. Богусевича щодо їі конструкції - по боках вона складалася 3 двох фасадних рядів плінфи, а простір між ними був забутований сумішшю вапняного розчину та фрагментів плінфи вторинного використання (Асєєв та Богусевич 1951, с. 39). Отримані матеріали дозволяють реконструювати ширину наземної частини стіни до 2 м.

Зі спорудженням мурів ця території зайняла периферійне положення 3 південно-західного боку монастиря. Вочевидь іiі використовували як господарчу зону для пожежонебезпечних виробництв. Навряд чи можна стверджувати про 

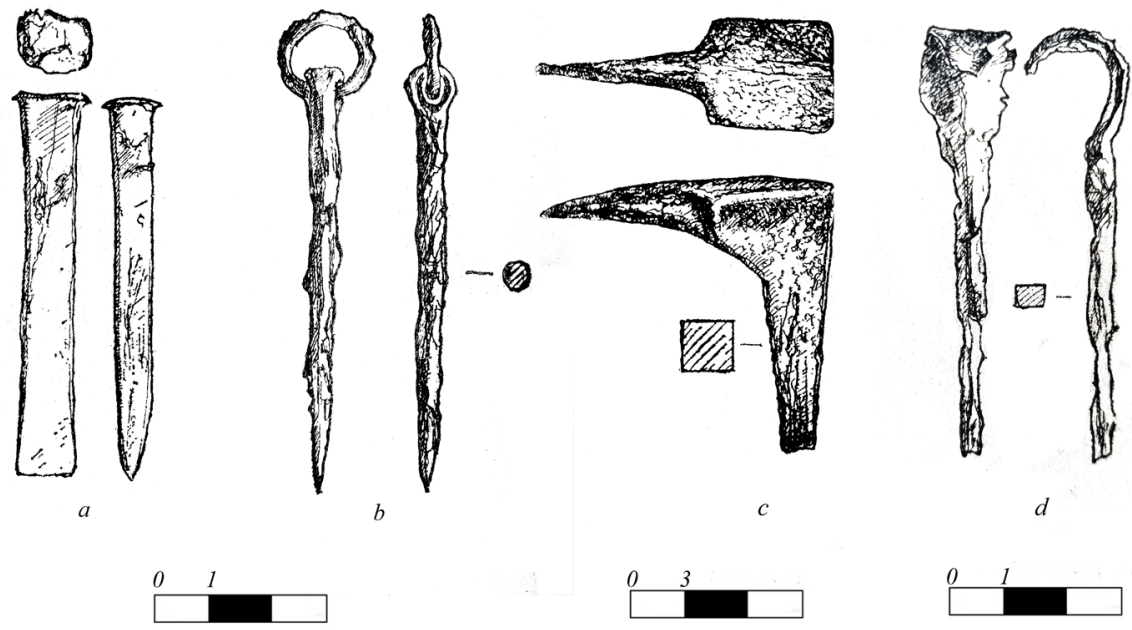

10. Матеріал з ковальського комплексу XIII-XIV ст.: зубило (a) та залізна шпилька (b) 3 заповнення споруди №2; ковадло (c) та токарний різець (d) з розчистки горну (розкопки В. Харламова 1987 р.)

наявність саду, хоча не виключена присутність будь-якої рослинності на цій території антропогенного походження, у тому числі.

Русько-Литовський період (друга пол. XIII-XVI cm.). Після Батиєвої навали на території Митрополичого саду виникає доволі потужна для цього часу поселенська структура зі стаціонарними житлово-господарськими спорудами і вираженими ознаками ремісничої спеціалізації. Такий висновок став можливим після створення Археологічної карти території Заповідника (Тараненко 2016; Тараненко, Мисько та Зажигалов, 2019) (рис. 2:88.1-7). Наявність та характер археологічних матеріалів другої половини XIII-XIV ст. дозволяє констатувати не лише факт безперервності монастирського життя в часи та після Батиєвої навали, але й початок формування на цьому етапі навколо монастиря первинних осередків майбутнього Печерського містечка, відомого у писемних джерелах з XVI-XVII ст. Необхідно зазначити, що традиція розміщення виробничих пожежонебезпечних комплексів на цій периферійній локації монастиря з часів Київської Русі достатньо чітко прослідковується й у цей період. Розкопки В. Харламова 1988 р. ковальського виробничого комплексу $є$ доказом цієї тези.

У західному куті споруди № 2 розміщалася піч розмірами 1,2 × 1,5 м (рис. 9). Ïї викладено з цегли-брущатки на глиняному розчині. Такий тип цегли характерний для XIV ст., хоча відомі випадки й раннього його використання. У заповненні споруди знайдено численні фрагменти кухонного, столового i тарного посуду другої половини XIII-XIV ст. Також зафіксовано достатньо 


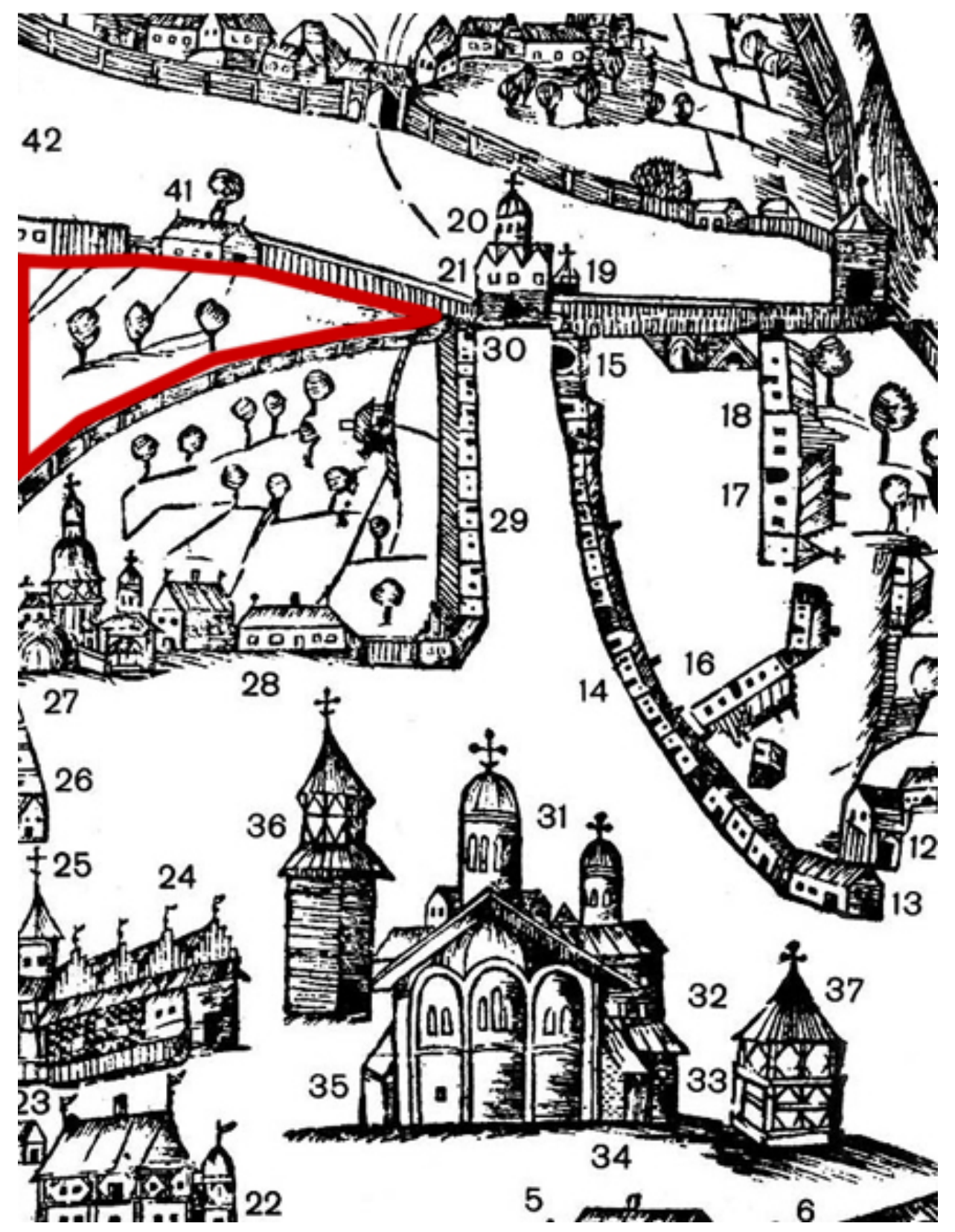

11. План Верхньої лаври з книги А. Кальнофойського „Тератургима” 1638 р. 
велику кількість виробів із заліза: ковані цвяхи з широкими та вузькими голівками, залізна шпилька для одягу з кільцеподібною рухомою голівкою довжиною 10 см (деталь одягу західно-балтійських племен [Седова 1981, с. 75]) (рис. 10: b); шість ножів довжиною 12-22 см, заготовка ножа (можливо кинджалу) довжиною 26 см. Окрім описаних залізних виробів, особливу увагу викликає знахідка ковальського інструменту в доброму стані - зубила (рис. 10: а). Авторами розкопок споруда реконструйована як житло коваля (Гончар 1993, с. 170-176). А саму майстерню вдалося виявити в 1,5 м від житла. Вона представляла собою горн (зафіксовано його нижню частину) та квадратну передгорнову яму, заповнену попелом і шлаком. Обидва об'єкти розміщалися під навісом. 3 розкопу походить матеріал, який свідчить про виробничий характер об'єкту: деревне вугілля, скупчення скляних і залізних шлаків та криці; частина сіроглиняного вогнетривкого конусоподібного сопла. Найяскравішими речами були інструменти - однорогове ковадло та токарний різець по дереву (рис. 10: с, d) (Гончар 1993 с. 178-180).

Специфічною особливістю Митрополичого саду є майже повна відсутність тут культурних нашарувань, об'єктів та археологічних матеріалів XV-XVI ст. На нашу думку, це пов’язано з тим, що саме у цей період починається формування саду - місця 3 культурними насадженнями в обмеженому просторі. Початком першого етапу формування можна вважати 1470 рік, після завершення капітального ремонту Успенського собору київським князем Симеоном Олельковичем. Такі потужні будівельні роботи могли супроводжуватися локальними переплануваннями території Верхньої лаври, що було дуже вдалим і логічним моментом для закладки саду. Руйнування Києва Менглі-Гераєм у 1482 р. могло призупинити цей процес, але, у будь-якому випадку, можна констатувати, що забудови на місці сучасного Митрополичого саду у XV ст. вже не існувало.

Культурні шари доби Модерну та Нового часу XVII-XIX ст. та незначні об'єкти фіксуються достатньо чітко, але їх наявність пов'язана вже виключно з господарською діяльністю у саду.

\section{ІСТОРІЯ ТЕРИТОРІЇ ЯК ІСНУЮЧОГО САДУ}

Не прямі археологічні дані не можуть поки стати надійним джерелом для чіткого датування створення саду. Тому краще спиратися на писемні та картографічні джерела, які проаналізував архітектор О. Романченко (Романченко 2017).

Про наявність садівництва в Києві та у Печерському монастирі після своєї подорожі 1584 р. повідомив купець та мандрівник М. Груневег. Описуючи лаврські печери, зазначав, що до них він йшов “через великий... сад”, а також зауважив, що практично кожен київський двір “має власний великий садок, 
город” (Ісаєвич 1981, с. 205). Австрійський дипломат Еріх Лясота, який побував у Києві в 1594 р., писав у своєму щоденнику: “від цього монастиря тягнеться під гору, вниз у напрямку річки сад, а в ньому є велике підземелля”, що “називають печерами” (Пащина, Калайда та Сокульський 2003, с. 225). Але найвідомішим описом монастирського саду $є$ свідчення Павла Халебського (Алеппського), який супроводжував свого батька патріарха Макарія до Московського царства у 1654 р. Він описав вхід до саду, який був оформлений у вигляді брами з банею, “утвореними зі штахетника й живоплоту завтовшки 3 лікоть” Живопліт з гілок “дерева, густі віти якого... густо вкрито шпичаками,... схожого на жасмин... Кожну гілочку, тільки-но вона випнеться 3-за штахетника обтинають ножицями. Така дивовижно гарна садова огорожа справа умілих садівникових рук. У цьому саду ростуть абрикоси й шовковиці... Крім цього, у саду безліч горіхів, а ще більше винограду”(Халебський, 2008, с. 138-139).. П. Халебський згадує також архімандритові келії, у вигляді великого будинку, верхній поверх якого увінчує висока баня з балюстрадою, звідки видно ріку Дніпро за монастирськими садами (Халебський, 2008, с. 138-139).

Слід зазначити, що назву «Митрополичий» сад отримав тільки після 1786 р., коли монастир втратив незалежний статус і його підпорядкували митрополиту Київському і Галицькому, який відтоді отримав титул священноархімандрита Києво-Печерської лаври. Будинок архімандрита став резиденцією митрополитів Київських і Галицьких, відповідно архімандричий сад став митрополичим (Романченко 2017, с. 235).

На відомих сьогодні планах Митрополичого саду XVII-XIX ст. не відображена вся складність та оригінальність його композиційно-розпланувальної структури, яка, зазнаючи певних змін, зберігалась упродовж декількох століть. Ïї зумовлював насамперед складний рельєф, на якому розкинувся сад. Рівнинна частина його простягалась від західного прясла оборонних мурів до умовної лінії східного фасаду архімандричих покоїв. Різкий перепад рельєфу утворював природну терасу, нижче якої на положистому схилі був розташований Нижній або Малий сад (Литвин 2020, с. 36).

Перше зображення саду вміщено на гравюрі Києво-Печерського монастиря у книзі А. Кальнофойського “Тератургима", виданій лаврською друкарнею 1638 р. (рис. 11). На цьому схематичному плані зображено фрагмент саду у вигляді території, обмеженої практично з усіх боків дерев'яними будівлями та спорудами. Така розпланувально-композиційна система є близькою до типу “замкнений сад”.

Значні перетворення у архімандричому саду відбулися наприкінці XVII ст. і пов'язані з розгортанням кам'яного будівництва на території Верхньої лаври. Територія саду стала значно меншою внаслідок будівництва мурованої огороджувальної стіни між спорудою архімандричих покоїв та західним пряслом монастирських оборонних мурів, що відмежувала частину території саду, на 


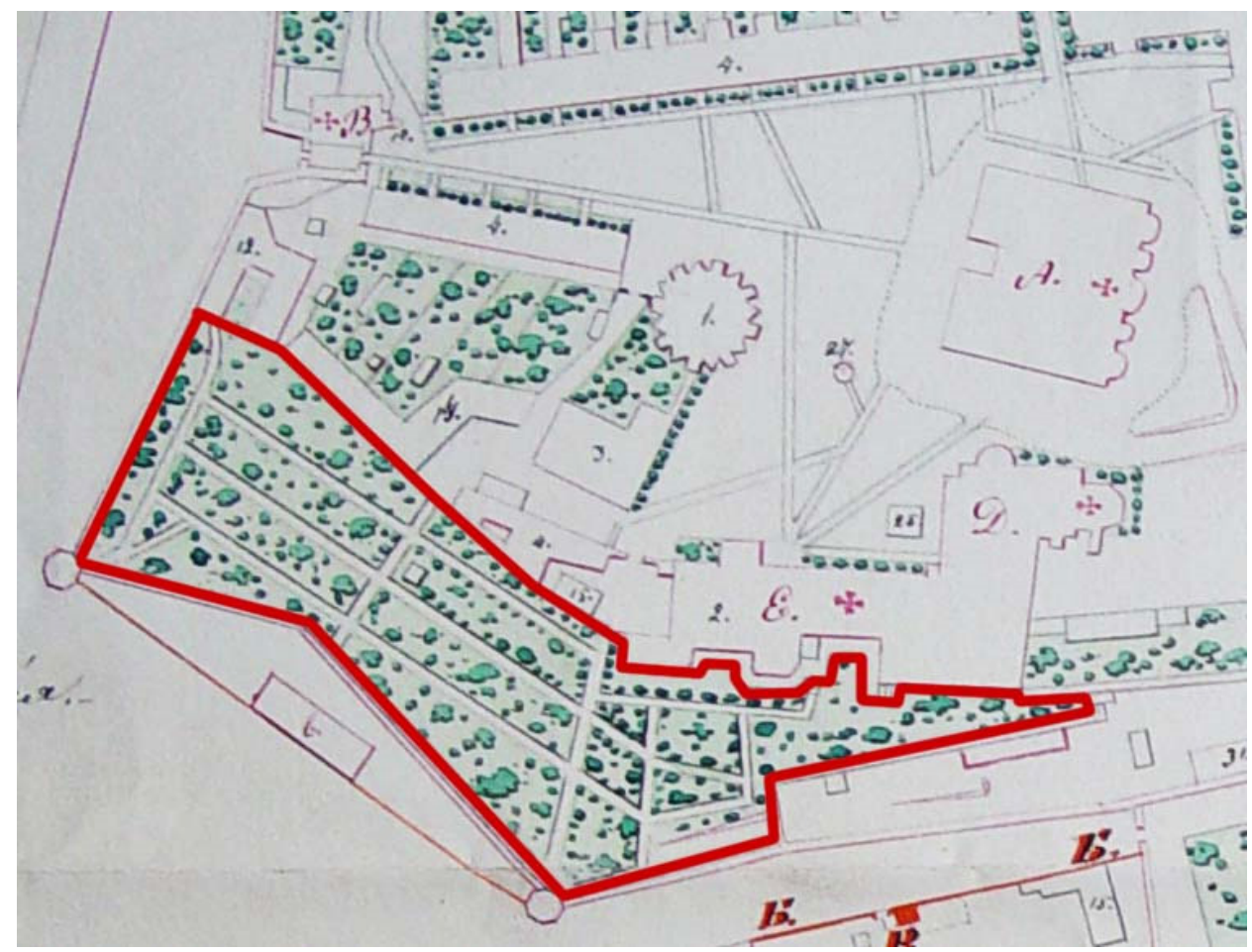

12. Фрагмент плану території Верхньої лаври. 1850 р.

якій згодом сформувався окремий сад при будинку намісника, однак він “выглядел очень скромно в сравнении с лаврским митрополичьим садом, во главе которого стоял опытный садовод” (Никодимов 1999, с. 56).

У XVIII ст. розпланувальна композиція саду і далі розвивається за принципом "замкненого саду”, започаткованим у XVII ст. Розміщення насаджень на території саду, згідно з тогочасними мистецькими вподобаннями, характеризується регулярністю. 3 30-х рр. XIX ст. лаврський Митрополичий сад, не втрачаючи регулярного планування, набуває рис “англійського” саду - 3 криволінійними доріжками, вільно розкиданими куртинами квітів, відмовою від вистригання дерев та чагарників (рис. 12). Розпланувальну систему садових доріжок, дерева та малі архітектурні форми, зокрема альтанки, які фіксуються на іконографічних матеріалах першої половини ХХ ст., втрачено після Другої світової війни. У повоєнний час плодові дерева висаджено без урахування історичної розпланувальної підоснови.

На думку О. Романченко, Митрополичий сад Києво-Печерської лаври є все ще недостатньо вивченим витвором садово-паркового мистецтва, закладеним в епоху бароко, який, окрім утилітарної, рекреаційної та естетичної цінності, 
може мати також певну символічну значущість, що відображає ідейно-філософські погляди тієї доби (Романченко 2017, с.236). Збереженість цієї природної (незважаючи на штучне походження) локації для майбутніх поколінь - основа сталого розвитку унікальної міської локації.

\section{ДОСЛІДЖЕННЯ РОСЛИННОСТІ}

Незважаючи, що навіть за нашою гіпотезою майбутній сад з'являється тільки у XV ст., вочевидь, що рослинність на території монастиря (заснованому в XI ст.) звичайно була. Підтверджених даних для давньоруського періоду ми не маємо, але вони існують стосовно центральної частині Верхнього Києва завдяки палінологічним та палеоботанічним дослідженням. Підтверджені таксони рослинності як природного походження, так і культивовані людиною: види дерев - дуб, сосна, липа, ясен, вільха, волоський горіх, ялина; садові - яблуня, слива, вишня; чагарники - малина, терен; огородні буряк, горох; лікарські - валеріана, материнка, конвалія звичайна, гірчак зміїний; декоративні - волошка синя, рутвиця орликолиста; велика кількість зернових культур та безліч бур'янових рослин (Тараненко та Янченко 2011).

Традиційним для лаврської флори, крім плодових (яблуня, вишня, горіх грецький) декоративних (липа серцелиста, клен гостролистий) дерев було садове квітникарство, яке вважалося однією із особливостей Києво-Печерського монастиря (Тараненко, Янченко та Сагайдак 2012). Також існують писемні підтвердження про існування в Архімандричому саду винограднику, який зберігався до кінця 1780-х рр. (Литвин 2018a, с. 77).

Найбільш популярними в лаврському садівництві XVIII ст. були сливи угорки, горіхи, груші, особливо дулі-зимниці, яблука, виноград. Саме ці плоди щорічно з лаврських садів відправляли до столу гетьмана Кирила Розумовського в Глухівський дім та до царського двору в Санкт-Петербург i Москву (Литвин 2018b, с. 72). Сортимент садових рослин у саду лаврського архімандрита урізноманітнювався завдяки і тим, що вирощували в оранжеpeї. Культура вирощування фруктових дерев у закритих приміщеннях в Києво-Печерській лаврі мала давню традицію. В архівних документах з історії лаврського садового господарства згадуються земляні хліви - попередники теплиць та оранжерей. У XVIII ст. в садах Києво-Печерської лаври було декілька оранжерей, в яких вирощували помаранчі, лимони, ананаси, інжир, персики та інші теплолюбні рослини. Була оранжерея і в саду архімандрита (Литвин 2020, с. 39).

Митрополичий сад, що був у віданні лаврської економії, разом 3 іншими лаврськими садами здавали у відкуп, тобто в оренду. Завдячуючи саме цій обставині, було створено унікальний документ, на підставі якого можна судити про сортове розмаїття Настоятельського саду в 20-х рр. ХІХ ст. Йдеться 


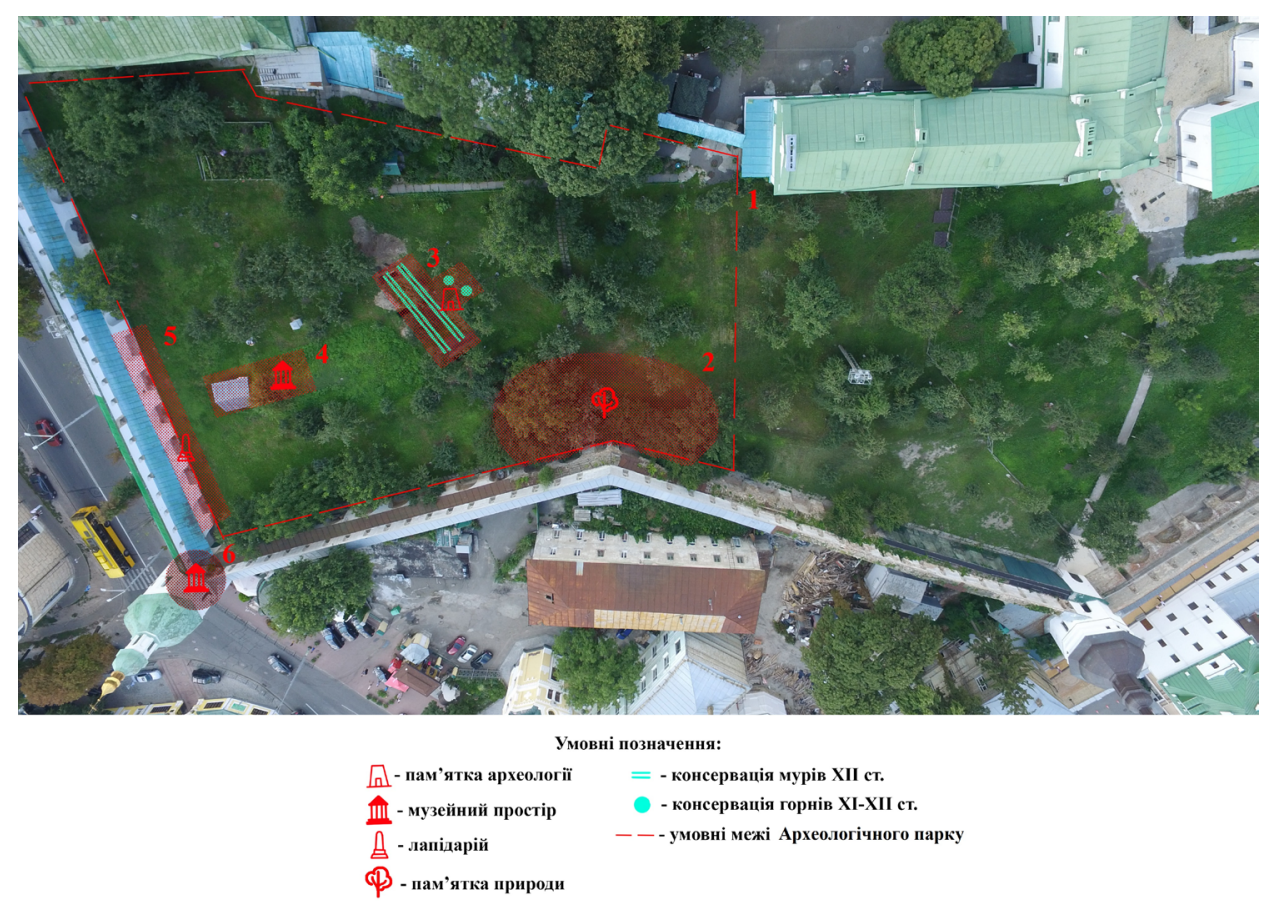

13. Схема розміщення об’єктів «Археологічного парку КПЛ»

про “Реестр сколько разного рода деревьев и кустов дерну состоит в саду, что внутри Лавры при Настоятельских покоях", складений внутрішнім економом Лаври ієромонахом Досифеєм і датований 9 червня 1824 р.

Згідно із зазначеним реєстром в Настоятельському саду, в 1824 р. загальна кількість становила 546 дерев. Серед них найбільше було слив - 215 дерев. Друге місце посідали грушеві дерева - 131, потім йшли яблуневі - 87. Окрім них, згадано також морелі, традиційні для Лаври волоські горіхи та кущі кизилу. Щодо сортового розмаїття, то найбільшою мірою воно було притаманне грушевим деревам. Лаврський економ нарахував в Настоятельському саду 13 сортів груш, серед яких французький сорт “принц-мадам", анафанівські, осиновки, “баби” тощо. А якщо згадати, що він зазначав і бергамотові дерева трьох різновидів - прості звичайні, французькі та зимові, то сортимент груш в Настоятельському саду збільшиться до 16. Сливові дерева, яких було найбільше за кількістю, представлені 6 сортами, а саме: гамбурзькі, угорки, сині, білі, туркені, кобили. Яблук вказано 5 сортів: білі, склянкові зимові, зерниці, путівки, солодкі (Литвин 2018b, с. 78).

На час складення реєстру в Настоятельському саду не припиняли багаторічну практику вирощування сіянців. Згідно з архівними джерелами, 1824 р. 
в розпліднику Митрополичого саду росли “молодые сеянцы ореховые, абрикосовые, персиковые и кустов дерна" (Литвин 2020, с.41).

За кількасотрічною традицією на території сучасного Митрополичого саду розміщається теплиця та оранжерея. Можливо, саме ця обставина може стати майданчиком для наукового відтворення давніх рослин та їх збереження.

\section{ПРОБЛЕМИ МУЗЕЄФІКАЦІЇ. АРХЕОЛОГІЧНИЙ ПАРК}

Після відкриття мурів ХІІ ст. Печерського монастиря у 2018 р. усі виявлені конструкції були законсервовані. Безумовно, археологічне дослідження більшої ділянки стіни може дати нові матеріали, які можливо дозволять звузити дату початку будівництва, виділити періоди ремонтних робіт або окремих етапів будівництва i, звичайно, загибелі конструкції. Така можливість існує, територія Митрополичого саду дозволяє відкрити трасу ділянки понад 20 м, але для цього повинно бути вирішене питання музеєфікації відкритих конструкцій ще перед початком археологічних досліджень. А враховуючі безпосередню близькість розміщення горнів склоробної майстерні ХІ ст., здається логічним об'єднання двох музеєфікованих об'єктів під одним дахом або накриттям.

Сучасна історична топографія південно-західної частини Митрополичого саду дозволяє використати Башту Кущника (як музей археології), ніші Мазепиних мурів XVIII ст. (як лапідарій), колишній винний льох XVIII ст. (як майданчик для експозицій) для створення Археологічного Парку Національного заповідника «Києво-Печерська лавра» (рис. 13).

\section{ВИСНОВКИ}

Вочевидь що територія саду вимагає професійного геолого-ландшафтного дослідження 3 метою реконструкції первинного рельєфу у рамках вивчення Печерського плато - сакральної зони давньоруського мегалополіса Київ.

Охорона історичних видів рослин та можливість їх культивувати - одне з обов'язкових умов для залучення процесу сталого розвитку цієї території.

Національний заповідник «Києво-Печерська лавра» має широкий потенціал для створення «Археологічного парку КПЛ». Це дозволить популяризувати археологію Кисво-Печерської лаври та зробити іiі відкритою для відвідувачів заповідника. Але для цього необхідно вирішити питання з музеєфікацією археологічних об’єктів, що лишається актуальним вже понад 70 років. У звіті В. Богусевича 1951 р. після першого відкриття мурів зазначено: «Комитет по делам культурно-просветительных учреждений при Совете Министров УССР и Государственный историко-культурный музей-заповедник 
Киево-Печерской Лавры предложили сделать сделать специальный экспозиционный павильон. К сожалению это мероприятие до сих пор еще не осуществлено» (Богусевич 1951, с. 12). Сподіваємося, що ми не будемо чекати ще десятиліття, для реалізації ідеї музеєфікації мурів. Сподіваємося, віримо і працюємо.

\section{СПИСОК ЛІТЕРАТУРИ}

Асєєв Ю., Богусевич В. 1951, Воєнно-оборонні стіни ХІІ ст. Києво-Печерської лаври, "Вісник Академії архітектури УРСР" 4, с. 39-45.

Балакін С. 2017, Пам'ятки первісних культур на теренах Києво-Печерської лаври, у С. Пивоваров та ін. (red.), Могилянські читання 2016. Музейництво і пам'яткоохоронна справа Украӥни: традииї та виклики сьогодення. Збірник наукових прачь, Київ, с. 120-127.

Безбородов М. 1956, Стеклоделие в древней Руси, Минск.

Богусевич В. 1951, Археологические раскопки в Заповеднике Киево-Печерской Лавры в 1951 г., Киев. Богусевич В. 1954, Мастерские ХІ в. по изготовлению стекла и смальты в Киеве, у П.Єфименко (ред.), Краткие сообщения Института археологии, Вып. 3. с. 14-20.

Гончар В. 1993, Археологічні дослідження колишнього митрополичого саду Києво-Печерської лаври у 1987-1988 рр., у П.Толочко (ред.), Стародавній Київ, Київ, с. 167-186.

Гречко Д. 2014, О бескурганных погребениях аборигенного населения Восточноевропейской лесостепи скифского времени, „Revista Arheologică, serie nouă”, Vol. 10, nr 1-2, p. 81-104.

Ісаєвич Я. 1981, Мартин Груневег і його опис Києва, у Коротич В. (ред.), „Всесвіт” 5, с. 204-211.

Литвин Н. 2018а, "Реєстри” економа Досифея - пам'ятка лаврського садівництва першоі третини XIX cm, w: С. Пивоваров та ін. (red.), Могилянські читання 2017. Збереження й дослідження культурної спадщини України: люди, ідеї, візії. Збірник наукових праць, Київ, c. $80-84$.

Литвин Н. 2018b, Монастирські фрукти та десерти в Лаврській дипломатії XVIII cm, w К. Крайній та ін. (ред.), Церква-наука-суспільство: питання взаємодії. Матеріали шістнадиятої міжннародної наукової конференції (29 травня - 2 червня 2018 р.), Київ, с. 71-74.

Литвин Н. 2020, Митрополичий сад Києво-Печерської лаври, w: К. Крайній та ін.(ред.), Церква наука - суспільство: питання взаємодії. Матеріали Вісімнадиятої Міжнародної наукової конферениї (травень-червень 2020 р.), Київ, с. 36-44.

Максимов Е., Петровская Е. 2008, Древности скифского времени Киевского Поднепровья, Полтава.

Никодимов И. 1999, Воспоминание о Киево-Печерской Лавре, Киев.

Пащина Л., Калайда Г., Сокульський А. 2003, Щоденник Еріха Лясоти із Стеблева, w: В.Смолій та ін. (ред.), Запорозька старовина, Київ-Запоріжжя, с. 222-277.

Романченко О. 2017, Формування розпланувальної структури Митрополичого саду Києво -Печерської лаври, w: К. Крайній та ін. (ред.), Церква - наука - суспільство. Матеріали n'ятнадиятої міжнародної конференції (29 травня - 3 червня 2017 р.), Київ, с. 231-236.

Седова В. 1981, Ювелирные изделия древнего Новгорода (X-XV вв.), Москва.

Тараненко С., Янченко В. 2011, Рослинний ландшафт Верхнього Києва у давньоруський час. Спроба реконструкиії, w: П. Толочко та ін. (ред.), Археологія і давня історія України. Вип. 5. Археологія: від джерел до реконструкиій, Київ, с. 227-230.

Тараненко С., Янченко В., Сагайдак М. 2011, До питання про реконструкцію рослинного ландшафту Верхнього Києва X-XIII cm. як природного, так і антропогенного характеру, w: К. Крайній (ред.), Болховітіновський щорічник 2011, Київ, с. 14-25.

Тараненко С. 2016, Археологическая Карта территории Киево-Печерской лавры: методика и перспективы исследования, w Patrimoniul cultural: cercetare, valorificare, promovare», editia a VIII-a (2016; Chisinau). Conferinta stiintifica international editia a VIII-a, Chisinau, 31 mai2 iunie 2016, Chisinau, p. 66. 
Тараненко С.П., Мисько Ю.В., Балакін С.А., Пабат О.О. 2018, Археологічні дослідження Митрополичого саду Києво-Печерської лаври у 2017 р., w: С. Пивоваров (ред.), Могилянські читання 2017. Збереження й дослідження культурної спадщини Украӥни: люди, візї. Збірник наукових праць, Київ, с. 178-183.

Тараненко С. 2019, Нове відкриття у 2018 р. мурів Києво-Печерського монастиря, w A. Zakościelna (red.), Badania archeologiczne w Polsce środkowowschodniej, zachodniej Białorusi i Ukrainie w roku 2018. Streszczenia wystapień, Lublin, s. 41-42.

Тараненко С.П., Мисько Ю.В., Зажигалов О.В. 2019, Археологічна карта Національного Києво-Печерського історико-культурного заповідника, Київ.

Тараненко С. 2019, До питання про „скіфський иар” на території Національного Києво -Печерського історико-культурного заповідника, w: С.Пивоваров (ред.), Могилянські читання 2019. Пам'ять $і$ пам'ятки Мазепиною доби: вивчення, збереження, осмислення. Збірник наукових праиь, Київ, с. 344-352.

Тараненко С., Кабанець С. 2019, Датування мурів Печерського монастиря: аналіз та критика джерельної бази, „Український історичний журнал” 3, с. 93-107.

Халебський П. 2008, Україна - земля козаків, Київ.

Asėèv Iũ., Bohusevych V. 1951, Voènno-oboronni stiny XII st. Kyèvo-Pechers'koï lavry, ,Visnyk Akademiï arkhitektury URSR" 4, s. 39-45.

Balakin S. 2017, Pam'iâtki pervisnykh kul'tur na terenakh Kyévo-Pechers 'koï lavry, u S.Pyvovarov ta in. (red.), Mohyliāns 'ki chytanniā 2016. Muzě̌nytștvo i pam 'iâtkookhironna sprava Ukraïny: trady-

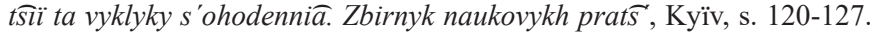

Bezborodov M. 1956, Steklodelie v drevně Rusi, Minsk.

Bogusevich V. 1951, Arkheologicheskie raskopki v Zapovednike Kievo-Pecherskou Lavry v 1951 g., Kiev.

Bogusevich V. 1954, Masterskie XI v. po izgotovleniiū stekla i smal'ty v Kieve, y. P. Ėfimenko (red.), Kratkie soobshcheniiā Instituta arkheologii, vyp. 3, s. 14-20.

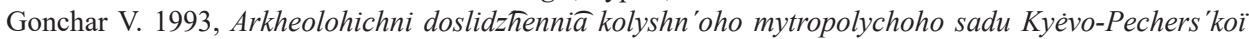
lavry u 1987-1988 rr., u P. Tolochko (red.), Starodavniü Kÿ̈v, Kyïv, s. 167-186.

Grechko D. 2014, O beskurgannykh pogrebeniiakh aborigennogo naseleniia Vostochnoevropeǐskoü lesostepi skifskogo vremeni, „Revista Arheologică, serie nouă”, vol. X, nr. 1-2, s. 81-104.

Isaèvych Ta. 1981, Martyn Hruneveh i ŭoho opys Kyéva, u V. Korotich (red.), ,Vsesvit” 5, s. $204-211$.

Lytvyn N. 2018a, „Reéstry” ekonoma Docyfeía - pam 'iatka lavros 'koho sadivnytstva pershö̈ tretyny

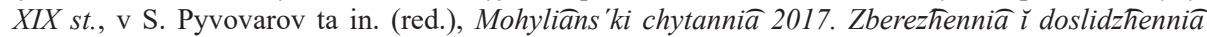
kul'turnoï spadshchyny Ukrä̈ny: liūdy, ideï, viziï. Zbirnyk naukovykh pratș, Kyïv, s. 120-127.

Lytvyn N. 2018b, Monastyrs'ki frukty ta deserty v Lavrs'kiü dyplomatï XVIII st., v K. Kraĭniŭ ta in.

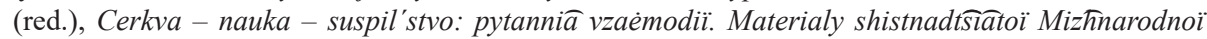
naukovoï konferentsiï (29 travniā - 2 chervniā 2018 r.), Kyïv, s. 71-74.

Lytvyn N. 2020, Mytropolychyı̌ sad Kyèvo-Pechers'koï lavry, w K. Kraĭniĭ ta in. (red.), Cerkva - nauka

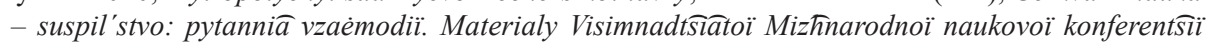
(traven'-cherven' 2020 r.), Kyïv, s. 36-44.

Maksimov E., Petrovskaiā E. 2008, Drevnosti skifskogo vremeni Kievskogo Podneprov'iā, Poltava.

Nikodimov I. 1999, Vospominanie o Kievo-Pecherskou Lavre, Kiev.

Pashchyna L., Kalaı̆da G., Sokul's'kyı̌ A. 2003, Shchodennyk Erikha Liasoty iz Stebleva, v V. Smoliı̌ ta in. (red.), Zaporoz'ka starovyna, Kyïv-Zaporizhzhia, s. 222-277.

Romanchenko O. 2017, Formuvanniā rozplanuval'nö̈ struktury Mytropolychoho sadu Kyèvo-Pechers'koï lavry, v K. Kraĭniı̆ na in. (red.), Cerkva - nauka - suspil'stvo: pytanniā vzaèmodiï. Materialy p 'iâtnadtsiatoï mizhnarodnoï naukovoï konferentsï (29 travniā - 3 chervniā 2017 r.), Kyïv, s. 231-236.

Sedova V. 1981, Î̃velirnye izdeliiâ drevnego Novgoroda (X-XV vv.), Moskva.

Taranenko S., Iânchenko V. 2011, Roslynnyı̆ landshaft Verkhn'oho Kyèva u davn'orus 'kyı̆ chas. Sproba rekonstruktsï̈, v P. Tolochko ta in. (red.), Arkheolohiia i davnia istoriîa Ukrä̈ny. Vyp. 5. Arkhe-

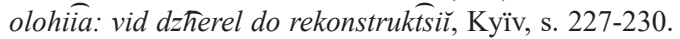


Taranenko S., Ianchenko V., Sahaĭdak M. 2011, Do pytanniā pro rekonstruktŝìū roslynnoho landshaftu Verkhn'oho Kyéva X-XIII st. iāk pryrodnoho, tak $i$ antropohennoho kharakteru, v K. Krăniü (red.), Bolkhovitinovs 'ky̆ shchorichnyk 2011. Kyïv, s. 14-25.

Taranenko S. 2016, Arkheologicheskaiā Karta territorii Kievo-Pecherskou lavry: metodika i perspektivy issledovaniia, $\mathrm{v}$ Patrimoniul cultural: cercetare, valorificare, promovare, editia a VIII-a (2016; Chisinau). Conferinta stiintifica international editia a VIII-a, Chisinau, 31 mai-2 iunie 2016, Chisinau, p. 66.

Taranenko S.P., Mis'ko Iû.V., Balakin S.A., Pabat O.O. 2018, Arkheolohichni doslidzhenniā Mytropolychoho sadu Kyėvo-Pechers'koï lavry u 2017 r., v S. Pyvovarov (red.), Mohyliâns'ki chytanniā 2017.

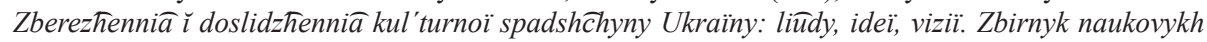
prat , Kyïv, s. 178-183.

Taranenko S. 2019, Nove vidkryttiā u 2018 r. muriv Kyèvo-Pechers'koho monastyriā, v A. Zakościelna (red.), Badania archeologiczne w Polsce środkowowschodniej, zachodniej Białorusi $i$ Ukrainie w roku 2018. Streszczenia wystapień, Lublin, s. 41-42.

Taranenko S.P., Mys'ko Iu..V., Zazhihalov O.V. 2019, Arkheolohichna karta Natşonal'noho Kyevo-Pechers 'koho istoryko-kul'turnoho zapovidnyka, Kyïv.

Taranenko S. 2019, Do pytanniā pro „skifs'kyl shar" na terytoriï Nats̄ionalnoho Kyèvo-Pechers'koho istoryko-kul'turnoho zapovinyka, v S. Pyvovarov (red.), Mohiliāns'ki chytanniā 2019. Pam 'iât' i pam 'iătky Mazepinoīu doby: vyvcherenniā, zberezhenniā, osmyslenniā. Zbirnyk naukowych praț , Kyïv, s. 344-352.

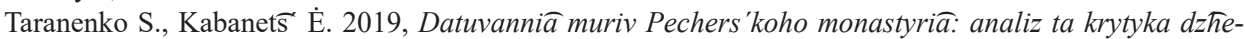
rel'noï bazy, „Ukraïns'kyı̌ istorychnyı̌ zhurnal” 3, s. 93-107.

Khalebs'kyĭ P., 2008, Ukraïna - zemiā kozakiv, Kyïv. 